\title{
The Fatwa Position of DSN-MUI in The National Banking System
}

\author{
${ }^{1}$ NENI SRI IMANIYATI, 2 PANJI ADAM \\ ${ }^{1}$ Fakultas Hukum, Universitas Islam Bandung, ${ }^{2}$ Fakultas Syariah, \\ Universitas Islam Bandung, Jl. Ranggagading No. 8 Bandung \\ email: ${ }^{1}$ imaniyati@yahoo.com; 2-panjiadam06@gmail.com
}

\begin{abstract}
The fatwa of DSN-MUI does not fit into the hierarchy of legislation. Therefore, it is necessary to conduct a research to know the fatwa position of the DSNMUI in the national banking system. This research proposed to understand the fatwa position of the DSN-MUI inthe national banking system and comprehend the rules and the principles in determining the fatwa of DSN-MUI. Results show that the Fatwa Status of DSN-MUI is as a source of sharia economic law. This refers to the Understanding of Sharia Principles in that Constitution that have the authority in determining the fatwa in the Islamic fields. The rules used by DSN-MUI in determining fatwas include al-muhâfadzah bi al-qadîm al-shâlh wa al-akhdzu bi al-jadîd al-ashlahnandal-ashlu fí al-mu'âmalât al-ibâhahah hatta yadullah dalîl 'alâ altahrîm. Basically all muamalah practices is permitted, except there is a proposition that forbid it. Besides that, the ulamas adhere to the main principles of muamalah, namely the principle of riba free, gharar, tadlîs, and maysir.
\end{abstract}

Keywords: position, fatwa of DSN-MUI, national banking

\section{Introduction}

The Fatwa of the National Sharia Board (DSN) of the Indonesian Ulema Council is one of the legal products resulting from an ijtihad. In general, ijtihad products can be differentiated into 4, namely (1) jurisprudence; (2) religious court decisions; (3) regulations; and (4) fatwas. Among the characteristics of ulema's fatwa - including the fatwa of the Indonesian Ulema Council (MUI) is casuistic because it is the response of answer to the questions posed by the fatwa's requesters. Based on those four products of ijtihad, there are two products which are binding each other and the rest are not binding. The two binding ijtihad products are religious court decisions and regulations. Regarding the regulations that is binding has a wide-bound in the community. The people involved in the formulation are not only limited to Ulema and fukaha (Islamic law scholar), but also politicians and other scholars (Panji Adam, 2013: 8-9).
The fatwa has a high position in Islam. It is seen as one of the alternatives that can solve the rigidity in the development of Islamic law and Islamic economics. The fatwa is an alternative to answer the development of the era that is not covered with religious texts (an-Nushûh al-Syar'iyah). The religious texts have quantitatively stopped, but problems and cases are diametrically growing along with the development of the era. In this condition, the fatwas become one of the alternative ways to reduce the emerging problems and events (Mardani, 2011: 215).

The fatwa is one of the institutions in Islamic law to provide answers and solutions towards the problems encountered by Muslims. Generally, Muslims make fatwa as a reference in attitude and behavior. It is because the position of fatwa among the citizens is like the postulate among the mujtahid. It means that position of fatwas for citizens towards the Islamic as the postulate for mujtahid. The existence of fatwas becomes

Received: December 01, 2016, Revision: March 31, 2017, Accepted: May 19, 2017

Print ISSN: 0215-8175; Online ISSN: 2303-2499.

Accredited by DIKTI. SK Kemendikbud, No.040/P/2014, valid 18-02-2014 until 18-02-2019, Indexed by DOAJ 
an organic aspect of sharia economic building which is being developed and also play as a measuring tool for the advancement of sharia economy in Indonesia. Sharia economic fatwa that has been presented technically serves the development model and figh muamalah māliyah updates and economic fiqh. Functionally, the fatwas have the task of tabyin and tawjih. Tabyin means to explain the law which is a practical regulation for financial institutions, especially requested by sharia economic practitioners to the National Sharia Board (DSN) (Hisranuddin, 2008: 77); tawjih means that the DSN provides guidance and enlightenment to the citizens about the norms of sharia economic law.

The implementation of a number of muamalah figh concepts is believed as the source of sharia economic system and banking, in the banking system, Bank Indonesia requires the help of Ulema (in this case MUI) to issue fatwas concerning economy and sharia banking. To respond to the growing interest of the citizens to do sharia muamalah, the MUI established the National Sharia Board (DSN) in Jakarta; and Sharia Supervisory Board (DPS) in each bank that is organized under the sharia system (Jaih Mubarok, 2004: 3).

National Sharia Board (DSN) was established through Decree of the Chairman of MUI No. Kep-754/MUI/II/1999 dated February 10,1999, with one of its duties is to issue a fatwa in the field of Islamic economy. This institute consists of Islamic law scholars (fukahâ), experts and economic practitioners, especially the financial sector, both banks and nonbank. Juridically, the National Sharia Board (DSN) is acknowledged in the Decree of the Directors of Bank Indonesia No. 32/34/1999 jo. Bank Indonesia Regulation No. 6/24/PBI/ 2004 concerning Commercial Banks based on sharia principles, as well as a supervisor of Sharia Supervisor Board (DPS) in various sharia financial institutions. In the Decree of the Chairman of MUI No. 754/MUI/ II/1999, it is determined that to carry out its business activities, the sharia commercial bank is obliged to pay attention to the fatwa of National Sharia Board (DSN).

One of the objectives of the DSN-MUI fatwa is to protect the operational Islamic financial institutions to run in accordance with the sharia principles. The fatwas issued by DSN are focused on the field of Islamic economy. The existence of the DSN fatwa becomes significant in sharia economic law development in Indonesia, hence sharia economic fatwa issued by DSN is actually have an attachment to material discussed in Compilation of Islamic Economic Law (KHES) (Juhaya S. Praja, 2012: 28).

The fatwa of DSN-MUI as one of the Islamic organizations fatwa in the Indonesian state system is not a positive law, so that it binds the Muslim community only. In addition, the state has no right to issue sanctions against those who issued the fatwa earlier (Zubari Hasan, 2009: 25).

In addition to its non-binding fatwa, the DSN fatwa is also not included in the hierarchy of laws and regulations in Indonesia, so the position of the DSN fatwa in the Islamic banking system in Indonesia is not an imperative positive law. Therefore, it is necessary to conduct research on the position of fatwa of DSN-MUI in the national sharia banking system.

This study examines the issues identified as follows: how is the fatwa position of the National Sharia Board of the Indonesian Ulema Council (DSN-MUI) in the national banking system and how are the rules and principles of the fatwa declaration of the National Sharia Board of the Indonesian Ulema Council (DSN-MUI). The purpose of this research is to understand the fatwa position of the National Sharia Board of the Indonesian Ulema Council (DSN-MUI) in the national banking system as well as to understand the rules and principles of the fatwa declaration of the National Sharia Board of the Indonesian Ulema Council (DSN-MUI).

\section{Methodology Research}

This research was conducted using normative juridical approach because this research places law as the norm, method, and principle. The characteristic of the research was analytical descriptive and the type of data used was secondary data. Secondary data consisted of primary legal materials, secondary legal materials, and tertiary legal materials. Technique of data retrieval is conducted by document study (library study/ library research). The data analysis technique used qualitative analysis in the form of discovery and interpretation of law.

Related to the fatwa position of the DSN MUI, the researchers that have been done before are: The Status of Fatwa of MUI in Efforts to Encourage the Implementation of Sharia Economy by Ahyar A. Gayo, (2011) and 
Fatwa Analyst of DSN MUI No. 92/DSN-MUI/IV 2014 about Financing accompanied by Rahn by Habib Wakidatul Ikhtiar, Postgraduate of IAIN Tulung Agung in 2014 (2016). In addition, other researchers is the Legal Aspects of the Fatwa of the DSN-MUI in the Operational Sharia Financial Institutions by Sainul and Muhamad Ibnu Afrelian, STAIN Jurai Siwo Metro (2015).

\section{The Fatwa Position of the National Sharia Board of the Indonesian Ulema Council (DSN-MUI) in the National Banking System}

Various sharia economic institutions have been developed in Indonesia for a long time, both bank financial institutions and nonbank financial institutions. The growth and development of financial institutions arisen from the sharia economic system brings some consequences to the operational legal basis of sharia-based financial institutions (Neni 2011: 152). This is because before the establishment of Islamic financial institutions, the activities of financial institutions based on the legal conventional system. One of the operational legal foundations of sharia financial institutions is the fatwa of DSN MUI. The DSN MUI has issued many fatwas related to the activities of sharia financial institutions, especially Sharia banking. Thus, the activities of sharia banking must not only refer to the applicable legislation but also to the Fatwa of the DSN-MUI. Basically, a formulation of the law is not just seen in terms of format in the form of law or judgment decisions only, but more importantly is the material content, whether it has been accommodating the values that are believed by the community and have fulfilled the sense of community justice or not. Sociologically, the Indonesian society explores normative values that people believe are confronted with religious values believed by Indonesian Muslims (2008: 31).

Eugen Ehrlich suggests that in the life of the nation and state, there is a balance between the desire to bring about legal reform through the regulations with the consciousness to pay attention to the living reality of society. The reality is called living law or just law which is the key of his theory. Eugen Ehrlich further argues that a good positive law is a law in accordance with living law as an inner order of society that reflects the values that live in it. If there is a desire to change the law, it is considered to notice the living law in that society in order that the law can be effectively valid (2008: 191).
The fatwa of DSN-MUI in the national banking legal system is only known since the operation of sharia banking in Indonesia, which began in 1992. Thus, at first the national banking legal system did not recognize the fatwa. The fatwas were appeared from the Islamic legal system, namely the form of ijtihad known in the Science of Jurisprudence. Although the fatwa of DSN-MUI is not included in the hierarchy legislation as regulated in Law No. 12 Year 2011 concerning Source of Law, but the fatwas for sharia banking practitioners have bound as the only legislation. According to Azizy (Azizy, 2002: 213-232), there are several advantages that can be gained from making juristic values into legislation; first, in the form of legislation, the legal material is more easily obtained and made as a guideline because its form is written and codified; second, in many cases, legislation has become the national codification and unification of laws and is no longer limited by certain regions, tribes, and classes; third, it is more easily to be understood and if there is a phrase to be interpreted, it is much easier than interpreting the unwritten law and causing much debate in the invention, especially in interpreting it; fourth, the risk for law enforcements is less than the existence of unwritten laws utilization or the courage to use ijtihâd in finding the law or allegations that the law enforcements have violated the law.

The practice of sharia banking in Indonesia initially based on the fatwa issued by DSN-MUI. The fatwa as stated in advance is one of the institutions in Islamic law to provide answers and solutions to the problems faced by the ummah. Even Muslims in general make the fatwa as a reference in attitude and behavior. The argument used is al-Fatâ fî Haqqil 'Âmi kal Adillah fî Haqqil Mujtahid, which means that the position of fatwa for the people is similar to the proposition for mujtahid (Mufti and Sula, 2007: 221).

The presence of these fatwas becomes an organic aspect of the Islamic economic building which was being laid out/developed, as well as becomes a measuring tool for the advancement of sharia economy in Indonesia. The sharia economic fatwa that has been presented is technically serving the development model and even the renewal of jurisprudence muamalah mâliyah (economic jurisprudence).

The muamalah jurisprudence is one of the disciplines of Islamic law. All the forms of the problems listed in the jurisprudence 
book are the questions from people or the problems that arise in society. Then the scholars gave their opinions according to the applied rules and then those opinions are recorded based on the results of the fatwas (Team Development Assistance LKS Bank Muamalat, 1999: 27).

The fatwa has the function of tabyîn and tawjîh. Tabyîn means to explain the law which is a practical regulation for financial institutions, especially those requested by sharia economic practitioners to the DSN. Then tawjîh means to provide guidance and enlightenment to the wider community about sharia economic norms (2007: 221).

In the study of ushul fiqh, the position of the fatwa is only to bind the person receiving and giving the fatwa. However, in this context, the theory is not entirely acceptable, since the context, characteristic, and character of the current fatwa have evolved and are different from the classical fatwa. The old theory of fatwas must be reformed and updated in accordance with its development and the process of fatwa formation. The fatwa theory that only binds to mustafa (people who ask for fatwas) is irrelevant for the DSN fatwa. Sharia economic fatwa is currently not only binding for practitioners of Islamic financial institutions, but also for all the Islamic community in Indonesia, especially the fatwas that has now become a positive law through Regulation of Bank Indonesia (PBI) (Umam, 2011: 74).

The current Islamic economic fatwas in Indonesia are issued through the processes and formulas of collective, institutional, and institutionalized called ijtihâd jamâ'î (ijtihad of ulema collectively), not ijtihâd fardî (individuals). The validity of jamâ'î and fardî is very different. Ijtihâd jamâ'î has approached the ijmâ' (2007: 221).

The fatwa in the classical definition is optional, "ikhtiyâriah" (the option which is not legally binding), whereas besides mustafi is "i'lâmiyah" or informative that is more than just a discourse. They are open to take the same fatwa or ask a fatwa to muftî/another expert.

If there is more than one fatwa on the same issue, then people may choose which one gives more qana'ah (acceptance/satisfaction) argumentatively. The characteristic of the fatwa distinguishes it from a judicial verdict (qadha) which has binding legal force for the litigants (2011: 74).
Fatwas authority on sharia economy in Indonesia as stated before is under DSN-MUI. The composition of its plenary consists of sharia's experts and economics/ financial experts who have sharia insights. In discussing the cases to be issued, DSN also involves partner institutions such as the Directorate of Banking Sharia from Bank Indonesia.

The classical definition of fatwa experiences the development and strengthening the positions in institutionalized and collective contemporary fatwas in Indonesia, both issued by the MUI Fatwa Commission for religious and social issues in general and taken out by the DSN for the subject of Islamic economics, especially sharia financial institutions. The fatwas issued by the MUI Fatwa Commission are generally accepted and binding moral reference for Muslims in Indonesia. At the same time, the fatwa DSN becomes binding references for the existing of LKS, as well as binding communities that interact with the LKS (2007: 222).

According to Nurhasanah (2013: 15), the fatwa of the DSN-MUI is a clerical product that represents its role in implementing and maintaining the principles of sharia in the economic field, especially Islamic Financial Institutions. Fatwas in principle belong to the domain of legal norms. The application of fatwas in Financial Institutions, especially banking - cursive from the author - is an attempt to realize sharia real-life norms that include the domain of legal application (no longer the domain of legal norms).

The fatwa of DSN-MUI as the guideline for operational sharia banking in 2005 is mostly made a substance in Bank Indonesia Regulation (PBI). This is seen in PBI No. $7 / 46 / \mathrm{PBI} / 2005$ concerning Agreement on the Collection and Distribution of Funds for Banks conducting business based on sharia principles. The purpose of the issuance of the PBI is to realize the similarities of the worldview of the sharia banking industry, including the managers of banks/owners of funds/users of funds, as well as the supervisor authority on the contracts of collecting funds products and the channeling of Islamic bank funds (Section b section Considering PBI No. 7/46 / PBI / 2005).

In its development, PBI no. 7/46/ PBI/2005 is revoked by PBI no. 9/19/ PBI/2007 concerning Implementation of Sharia Principles in Funds and Disbursement Activities of Funds and Services of Bank 
Sharia. Fatwa content material is no longer contained in the PBI. 9/19/PBI/2007, but it is included in Circular Letter of Bank Indonesia No. SEBI. 10/14/DPbS Jakarta, March 17, 2008 concerning the Implementation of Sharia Principles in Collecting Activities of Funds and Disbursements and Services of Bank Sharia (2011: 75).

The existence of PBI and SEBI indicated that the existence of the DSN-MUI fatwa is legally recognized. The existence of the DSN-MUI fatwa is getting stronger after the enactment of Law No. 21 Year 2008 regarding Sharia Banking. The article 1 point 12 of the Act is expressly stipulated that "Sharia Principle is the principle of Islamic law in the banking activities based on the fatwa issued by the institution having authority in the determination of fatwa in the field of sharia". Although it is not explicitly pointed out to DSN-MUI, but according to Khotibul Umam based on the empirical reality of existing institutions that have an authority in the determination of fatwa in the field of sharia, namely DSN-MUI.

With the enactment of Law No. 21 year 2011 on the Financial Services Authority, hence the authority of Bank Indonesia related to the making of regulations, licensing, guidance and supervision of Financial Institutions, including banks switch to Financial Service Authority (OJK). Therefore, the making of regulations including those whose material has been addressed in the DSN Fatwa is reinforced by OJK Rules.

Umam, further argued that because the fatwa of DSN-MUI is appointed by law, then the power of this behavior is legally strong. Therefore, if the Sharia Bank does not implement the provisions contained in the fatwa on certain products, then it may be sanctioned by the competent authority, such as Bank Indonesia. When there is no regulatory authority that recognizes the existence of DSN-MUI and its products in the form of fatwas, the fatwa's belief is based more on living law (2011: 76).

Thus, borrowing the teachings from Eugen Ehrlich, the desire to make legal reform through legislation, namely in the field of Islamic banking has been balanced with awareness or reality living in society. Consequently, the existing legislation, namely Law no. 21 year 2008 concerning Sharia Banking and Bank Indonesia Regulation which is now the OJK Regulation - as its implementing regulation, will have effective behavior, as well as the DSN-MUI fatwa.

\section{The Rules and Principles of the Fatwa Determination of National Sharia Board of Indonesian Ulema Council (DSN-MUI)}

There are three approaches done by DSN-MUI in responding to a new economic law problematic: first, seeking solutions through the qath'î proposition (definite, firm, and clear), second, referring to the opinions of ulema (aqwâl 'ulamâ), if there are differences among scholars then it is sought the point of equation and do tarjîh (choosing the strongest opinion), third, doing ilhaqi approach (finding the equivalent of a similar case in classical Islamic law which is also the result of ijthad of branch law scholars) if there is no first and second points (Amin, 2006: 1).

The existence of classical jurisprudence muamalah is not entirely relevant anymore to be applied because the forms and patterns of transactions developed in this modern era are so fast. Socio-economic and business of communities have changed considerably compared to past conditions. Therefore, in this context two rules are applied (2007: 222).

First, al-muhâfadzah bi al-qadîm alshâlh wa al-akhdzu bi al-jadîd al-ashlah, which maintains a classical intellectual heritage that is still relevant and continuely practiced in modern times, as long as there is no instruction to prohibit it. Second, al-ashlu fî al-mu'âmalât al-ibâhah hatta yadullah dalîl 'alâ al-tahrîm, which is basically all muamalah practices are permitted, unless there is a proposition that forbid it.

In addition, the scholars cling to the main principles of muamalah, such as the principle of free usury, free of gharâr (uncertainty or uncertainty) and tadlîs, not maysir (speculative), free illicit products and fasid/vanity contract practices. This principle should not be violated because it has become an axiom in the jurisprudence of muamalah (2007: 223).

The fatwa formulation also adheres to the principle of maslahah or "ashlahah", ie which one is maslahat or more maslahat to be used as a option to create a fatwa. The concept of maslahah in muamalah becomes the most important principle. In the ushul jurisprudence has a popular rule, "where there is maslahah, there is the sharia of Allah". The character of maslahah syar'iyyah, among others take side of all parties or 
generally accepted, both maslahat for sharia institutions, customers, government (regulator), and the wider community.

Welfare is not only recognized in tanzhiriyah (theoretical calculations), but also in tajribiyah (the empirical experience in the field). Therefore, to examine the fatwa shalahiyah (validity), marja'ah maidaniyah (field matching) should be held after a sufficient period of time in the implementation of economic fatwa to justify the benefit in the theoretical level for its application in the field.

\section{Conclusions}

Based on the result of the research, it can be concluded that the fatwa position of DSN-MUI after the enactment of Law No. 21 Year 2008 concerning Sharia Banking is as a source of sharia economic law. This refers to the definition of sharia principles in the constitution namely the principle of Islamic law in the banking activities based on fatwas is issued by institutions that have authority in the determination of fatwa in the field of sharia. Although, it is not explicitly pointed DSN-MUI, based on the empirical reality of institutions, a council that have authority in the establishment of fatwa in the field of sharia is DSN-MUI. Thus, the fatwa position of the DSN-MUI has a strong position as a source of Sharia Economic law in Indonesia.

The rules used by DSN-MUI in establishing fatwas include: first, al-muhâfadzah bi alqadîm al-shâlh wa al-akhdzu bi al-jadîd alashlah, which maintains a classical intellectual heritage that is still relevant and the practice continue to exist in modern times, as long as there is no instructions to prohibit it; second, al-ashlu fî al-mu'âmalât al-ibâhah hatta yadullah dalîl 'alâ al-tahrîm, which basically permits all muamalah practice except there is a proposition that forbid it. In addition, the scholars adhere to the main principles of muamalah, such as the principle of free usury, free of gharar (uncertainty or uncertainty) and tadlîs, not maysir (speculative), free of illicit products and practices of fâsid/vanity.

Based on the above conclusions, several suggestions are proposed, namely in running the business activities, sharia financial institutions should be guided by the fatwas issued by DSN-MUI. To respond to the people needs in the field of sharia economy, DSN is expected to take out a fatwa in accordance with the development of sharia economy in Indonesia.

\section{References}

Adam, P. (2013). Analisis terhadap Fatwa Dewan Syariah Nasional (DSN) MUI Nomor 13 Tahun 2000 tentang Uang Muka dalam Murabahah. Thesis: UIN Bandung.

Amin, M. (2006, July 11-12). Kompilasi Nash dan HUjjah Syari'yyah Bidang Ekonomi Syariah. (M. Amin, Performer) Jakarta, DKI Jakarta, Indonesia.

Azizy, A. Q. (2002). Eklektisisme Hukum Nasional ompetensi antara Hukum Islam dan Hukum Umum. Yogyakarta: Gema Media.

DSN-MUI. (2001). Himpunan Fatwa DSN-MUI.

Gayo, A. A. (2001). Kedudukan Fatwa MUI dalam Upaya Mendorong Pelaksanaan Ekonomi Syariah. Jakarta: BPHN.

Hasan, Z. (2009). Undang-Undang Perbankan Syariah: Titik Temu Hukum Islam dan Hukum Nasional. Jakarta: PT. Raja Grafindo Persada.

Hisranuddin. (2008). Hukum Perbankan Syariah di Indonesia: Pembiayaan Bisnis dengan Prinsi Kemitraan. Yogyakarta: Genta Press.

Ikhtiar, H. W. (2016 ). Analis Fatwa DSNMUI No.92/DSN-MUI/IV 2014 tentang Pembiayaan yang disertai Rahn. An Nisbah. Vo.3 No 1

Imaniyati, N. S. (2011). Asas dan Jenis Akad dalam Hukum Ekonomi Syariah: Implementasinya pada Usaha Bank Syariah. Mimbar Jurnal Sosial Humaniora, Vo. XXVII No 2

Mardani. (2011). Hukum Ekonomi Syariah di Indonesia. Bandung: Refika Aditama.

Muamalat, T. A. (1999). Perbankan Syariah: Perspektif Praktis. Jakarta: Muamalat Institute.

Mubarok, J. (2004). Perkembangan Fatwa Ekoomi Syariah di Indonesia. Bandung: Pustaka Bani Quraisyi.

Mufti, A., \& Sula, M. S. (2007). Amanan bagi Bangsa: Konsep Sistem Ekonomi Syariah. Jakarta: Masyarakat Ekonomi Syariah.

Nurhasanah, N. (2013). Pengawasan Islam dalam Operasional Lembaga Keuangan Syariah. Mimbar Jurnal Sosial Humaniora,Vol. 29.No. 1 pp 15.

PBI. (2005). PBI no. 7/46/PBI/2005 tentang Akad Penghimpunan dan Penyaluran Dana bagi Bank yang Melaksanakan Kegiatan Usaha Berdasarkan Prinsip Syariah.

PBI. (2007). PBI No.9/19/PBI/2007 tentang Pelaksanaan Prinsip Syariah dalam Kegiatan Penghimpunan Dana dan penyaluran Dana serta Pelayanan Jasa Bank Syariah. 
Praja, J. S. (2012). Ekonomi Syariah. Bandung: Pustaka Setia.

Saiunul, \& Afrelian, M. I. (2015). Aspek Hukum Fatwa DSN-MUI dalam Operasional Lembaga Keuangan Syariah. Jurnal Hukum dan Ekonomi Syariah,Vo.3 No 2.

SEBI. Surat Edaran Bank Indonesia (SEBI) No. 10/14/DPbS perihal pelaksanaan Prinsip Syariah dalam Kegiatan Penghimpunan
Dana dan Penyaluran Dana serta Pelayanan Jasa Bank Syariah.

Umam, K. (2011). Legislasi Fikih Ekonomi dan Penerapannya dalam Produk Perbankan Syariah di Indonesia. Yogyakarta: BPFEYogyakarta.

Undang-Undang Nomor 21 Tahun 2008 tentang Perbankan Syariah. 